\title{
Students' Spatial Reasoning in Solving Geometrical Problems Based on Personality Types
}

\author{
Aprilia Lutfitasari \\ Mathematics Education, Universitas Negeri Surabaya, \\ Indonesia \\ aprilialutfitasari16070785020@mhs.unesa.ac.id
}

\author{
Siti Maghfirotun Amin, Masriyah \\ Department of Mathematics, Universitas Negeri \\ Surabaya, Indonesia \\ sitiamin@unesa.ac.id, masriyah@unesa.ac.id
}

\begin{abstract}
Student's spatial reasoning is the process of manipulating objects that can help students to solving the daily problems about spatial. The aim of this study was to know students' spatial reasoning in solving geometry problems based on personality types. This study was used qualitative descriptive approach to examine four participants which represented each type of Keirsey's personality called "The Keirsey Temperament Sorter". The data were collected from spatial reasoning task and interview. The results showed every personalities types had different ability of spatial reasoning in solving geometry problem. In spatial visualization, students who had guardian and artisan personalities could identify the figure with their sensing. The rational student identified the figure with his knowledge. The idealist student had experienced difficulties to identify the figure. In mental rotation guardian and idealist student could imagined the figure that has been rotated. The idealist student had seen the pattern of the figure to solving the problem. The artisan and rational student had answered with the wrong answer. Because the rational student just focused in angle but ignore direction of the figure and the artisan student had answered in a hurry. In spatial orientation guardian and artisan personalities had drawn with details. The rational personalities had drawn without regard the size of the figure.
\end{abstract}

Keywords- Geometrical Problem, Personality Type, Spatial Reasoning.

\section{INTRODUCTION}

Mathematics is a tool and language to solve big and small problems [2]. In Mathematics lesson, one of the high performance support of high school students who could solve geometry problems is related to waking up, understand the nature of geometry related to emphasis, intersection, geometry, and provide insight by using geometric visualization [7]. The activity of visualizing geometry includes in spatial reasoning. The spatial reasoning of process was to recognize the ability of object spatial objects and the spatial relations between the objects [12]. Spatial reasoning is the process of measuring objects and symbols [16]. Spatial reasoning supports our understanding of our geometric world, from which allows us to navigate our surroundings, position furniture in a room, and visualize a diagram when solving a mathematics problem [10].

Spatial reasoning had three components: spatial visualization, mental rotation and spatial orientation [15]. Spatial visualization was manipulating spatial patterned images into different views. Mental rotation dealt with solving mental problems quickly without seeing the rotation itself. Spatial orientation was imagining objects from different angles. The indicator of the spatial visualization used in this studycan be seen in Table 1.

TABLE I. SPATIAL REASONING INDICATORS

\begin{tabular}{|l|l|}
\hline \multicolumn{1}{c|}{$\begin{array}{c}\text { Component of } \\
\text { Spatial Reasoning }\end{array}$} & \multicolumn{1}{c|}{ Indicators in This Research } \\
\hline Spatial Visualization & $\begin{array}{l}\text { Create 3 dimensional figure webs. } \\
\text { Build 3-dimensional figures from familiar } \\
\text { webs. } \\
\text { Matching parts of a figure. }\end{array}$ \\
\hline Mental Rotation & $\begin{array}{l}\text { Determine the result of rotation toward a 3- } \\
\text { dimensional figure that rotates clockwise or } \\
\text { counterclockwise. }\end{array}$ \\
\hline Spatial Orientation & $\begin{array}{l}\text { Draw the representation of a 3-dimensional } \\
\text { figure that shown from different angles. }\end{array}$ \\
\hline
\end{tabular}

Visual and spatial images were focused on spatial reasoning [8]. Spatial thinking could be implemented in everyday activities such as seeking understanding in reading maps, and distance concepts [1].

The results of research by Prabowo et al. suggest that the students' problems with the students' level of abstractness is very high and reduces students' spatial visualization [14]. The same thing was reported by Ryu et al. said that from 7 students there are still 5 students who couldn't perform tasks in manipulating spatial objects [17]. Many students learn about geometry related to form and space [18]. In several statements that have been conveyed, spatial reasoning is very closely studied with geometry. Some student difficulties have shown that to support geometric solutions, students need spatial reasoning.

Every different personality had different strategies to solve problems, choose the effectiveness of the process, selected alternatives and techniques that could solve the problem [3]. Similarly, presented by [9], there was a strong correlation between personality types and problem solving. Based on those facts, it could be said that each individual solved the problem in different ways according to their personality types. 
Personality was a concept of abstraction or hypothetical that was best conceptualized as the amount of one's behavior in various situations [13]. Personality might be seen not as part of the mind, but as an observable behavior. Personality was reflected in every person's behavior. Observable behavior was included speaking, behaving, making decisions and thinking. Personality was facilitating learning behavior and motivating people, and the traits that determine a person in continuing to struggle or surrender. It could be said that personality affects a person to make decisions [4]. In a line with those statements, personality was a characteristic feature of the innate person causing the appearance of certain feelings, thoughts, and behaviors [11].

Personality types were classified based on how a person obtained his energy, obtained information, made decisions and lifestyles [5]. Keirsey's personality type was often known as Keirsey Temperament Sorter (KTS). KTS was classified into four types: guardian, artisan, rational, and idealist.

The transition of childhood into adulthood called adolescence. It was in children aged 15-18 years [18]. Students at senior high school were categorized as teenagers because they have age between 15-18 years. Therefore, reasoning would be more visible in students who were in adolescence. In adolescence, students were expected to be invited to communicate better and could do the task given. Adolescence students had been able to choose decisions about what was preferred to do and vice versa, it affected the formation of one's personality. Student was troubleshooting in varied spatial reasoning tasks [18].

\section{METHOD}

The research used descriptive research with qualitative approach. The purpose of this research was describing students' spatial reasoning in solving geometry problems in geometric material in terms of guardian, artisan, idealist and rational personality type. In determining the subject of research, the students were given the Personality Type Test (TPTK) adapted from "The Keirsey Temperament Sorter" and consists of 70 questions. The selected subject of upper secondary schools might have equal ability and the same sex. Selected four subjects representing each personality type and had equivalent mathematical abilities. First of all, a selected group of students would be given TPTK and Mathematics Capability Test (MCT).

Technique of data collecting was done by giving MCT. The results of the test would be a benchmark to categorize students whose low mathematics skills with the value of MCT, medium math skills with the value of MCT and students of high mathematics skills with MCT scores. The Mathematics Capability Test (MCT) in the research was made by researcher adopted from the mathematics' national exam of senior high school from year of 2015 until 2017. MCT consisted of 10 items of national exam questions with the form of multiple choices that had been changed into a matter of essay. Problems of multiple choices could raise the possibility of students to choose answers randomly without thinking. MCT had consulted to supervisor lecturer and validated by two persons, they were lecturers of mathematics who had a minimum of master's degree and one senior mathematics teacher who had been teaching for at least 5 years and test of legibility by students. Instrument readability test was done by giving students a questionnaire that contained some questions about readability of writing, readability of content, understanding students about the questions and suggestions of the reader. The test was given to obtain data from students' math skills. This was done to avoid the selection of subjects who have relatively unequal mathematical abilities.

Selection of research subjects should have equal mathematical abilities. It was selected subjects whose high capability. Then, it was chosen four students represented each personality type and also had high mathematical abilities. Researcher did not take students whose low math skills, it was done to avoid the condition if the subject couldn't do the given problem-solving task.

In addition, the selection of subjects was also selected by taking into account the communication skills possessed by students, the communication skills possessed must be relatively good for the data taken in accordance with the expectations of researchers. The researcher would consult with the mathematics teacher in the class to select students who have good communication skills. Problem solving and interviewing students were based on the task they have done. The data of each subject was shown on Table 2.

TABLE II. RESEARCH SUBJECT DATA

\begin{tabular}{|l|l|l|l|l|l|}
\hline $\begin{array}{l}\text { Initial } \\
\text { Name }\end{array}$ & Sex & $\begin{array}{c}\text { MCT } \\
\text { Score }\end{array}$ & $\begin{array}{c}\text { Categories of } \\
\text { Mathematical } \\
\text { Abilities }\end{array}$ & $\begin{array}{c}\text { Personality } \\
\text { type }\end{array}$ & $\begin{array}{c}\text { Subject } \\
\text { Code }\end{array}$ \\
\hline IDP & L & 82 & High & Artisan & AR \\
\hline HAR & L & 95 & High & Guardian & GU \\
\hline MRS & L & 91 & High & Rational & RA \\
\hline NR & L & 90 & high & Idealist & ID \\
\hline
\end{tabular}

In Table 2, there were 4 students who respectively had guardian, idealist, rational, and artisan personality types. The four students also had equal mathematical abilities that were highly capable. The sex of the four students who would be used was male.

After obtaining the value of the subject that meets the requirements, subjects were given 3 problems that existed in Problem Solving Task (PST). The three problems represented spatial visualization problems, mental rotation, and spatial orientation. After the students did the PST, each student was interviewed based on the PST that had been done. One or two weeks after PST1, the subject was given PST2 as the data triangulation process. Then, the data were analyzed. After the data analysis process was complete then it would be made a conclusion about the research that has been done. The final step is making a research report 


\section{RESULTS AND DISCUSSION}

A. Spatial Reasoning of Guardian Students

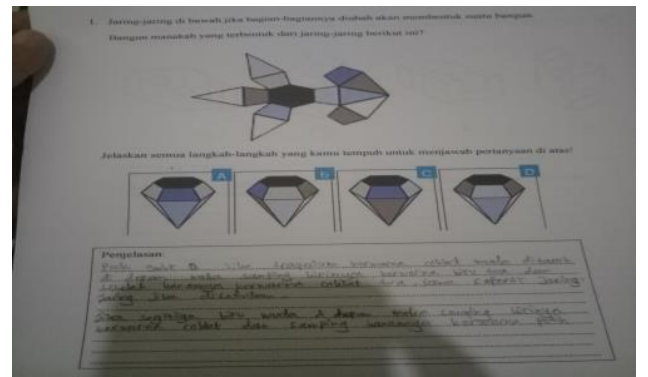

Figure 1: The Guardian Type in Spatial Visualization Problem

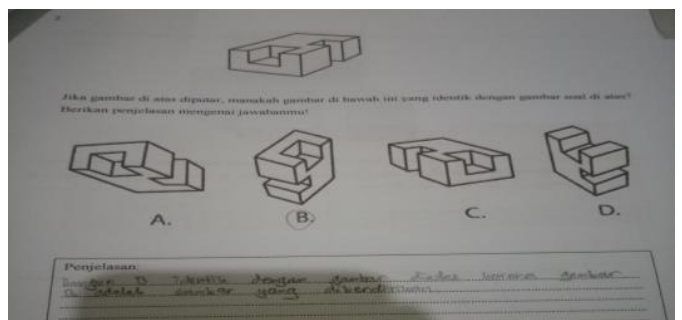

Figure 2: The Guardian Type in Mental Rotation Problem

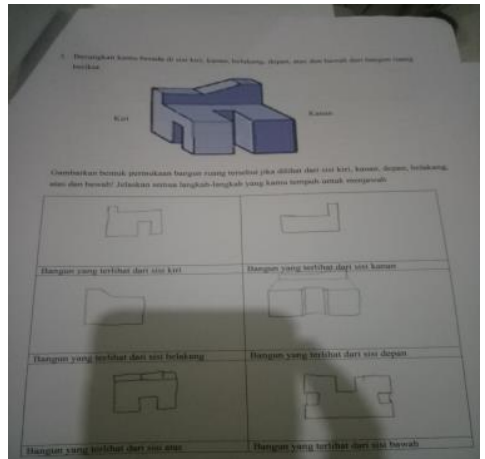

Figure 3: The Guardian Type in Spatial Orientation Problem

In spatial visualization, the guardian student was able to understand the image appropriately. The guardian student used the given information to solve the given problem. This could be seen from the explanation on the answer that states some parts of the shape of the figure properly. Furthermore, students could also match the shape of the figure that had been changed with the initial figure. In the mental rotation, guardian student could also determine the correct result of the given figure. In the given explanation, students identified the figure based on the facts. This indicated that the student was getting information with sensing and it was accordance with the characteristics of the guardian type. In Spatial orientation, guardian student was very detail in imagining the objects.
B. Spatial Reasoning of Rational Students

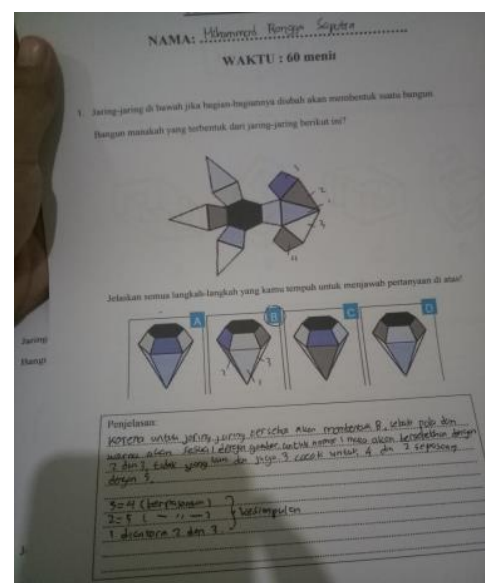

Figure 4: The Rational Type in Spatial Visualization Problem

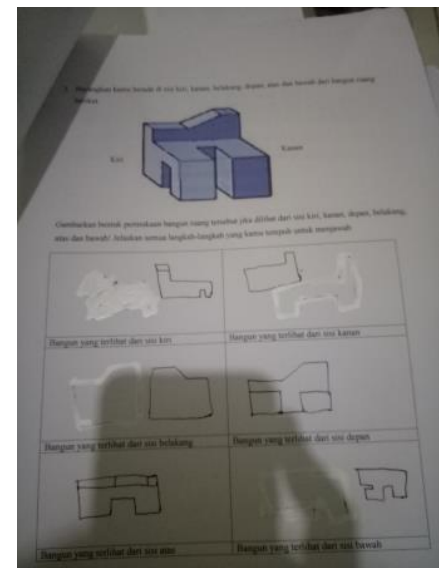

Figure 5: The Rational Type in Mental Rotation Problem

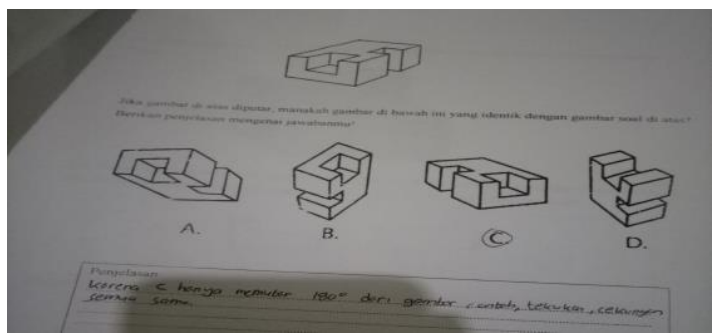

Figure 6: The Rational Type in Spatial Orientation Problem

In spatial visualization, rational student identified figures by using symbols on some parts of the figure to make it easier for students to solve problems. The student could also observe the pattern in the picture. The rational type had intuitive characteristics [5]. In mental rotation, the rational student answered the problem with the wrong answer. The student thought that the figure had been rotated $180^{\circ}$ and ignored the figure's direction after a rotation. In spatial orientation, the rational student described figures that were seen with less proportional size with a known figure. From the student's explanation, it was obtained results that the figures were shown by symbols such as using letter " $h "$, letter " $y "$, the surface, the base, etc. Students also used the information to solve the 
problem. It was shown on student's explanation that mentioned some known 2D figure names.

\section{Spatial Reasoning of Idealist Students}

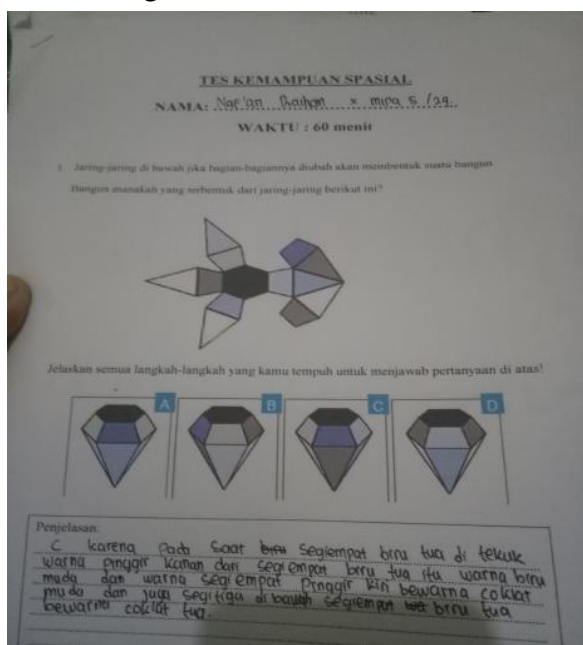

Figure 7: The Idealist Type in Spatial Visualization Problem

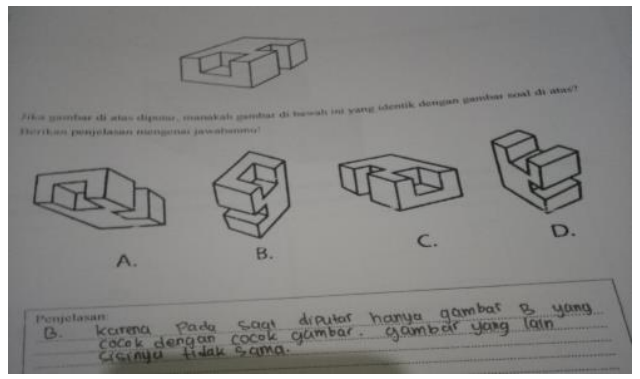

Figure 8: The Idealist Type in Mental Rotation Problem

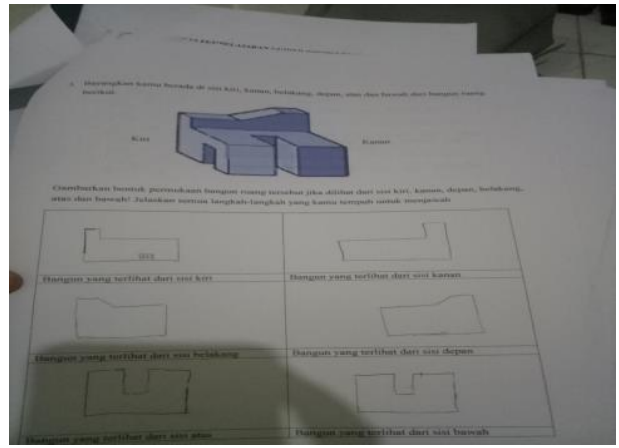

Figure 9: The Idealist Type in Spatial Orientation Problem

In spatial visualization, students' answers were incorrect on problems related to spatial visualization. Idealist student was not a good observer. It could be seen from his explanations that stated the location of some incorrect figure sections. In mental rotation, student could know that the option other than B was a figure which was not the same as the figure on the question. In the explanatory column, idealistic student seemed to prefer things that contained paragraph-shaped descriptions. In spatial orientation, students were less able to describe in detail the figure when seen from different angles. The side that illustrated, by the students, was also not precise. Therefore, it could be stated that student did not observe the figure thoroughly.

\section{Spatial Reasoning of Artistic Students}

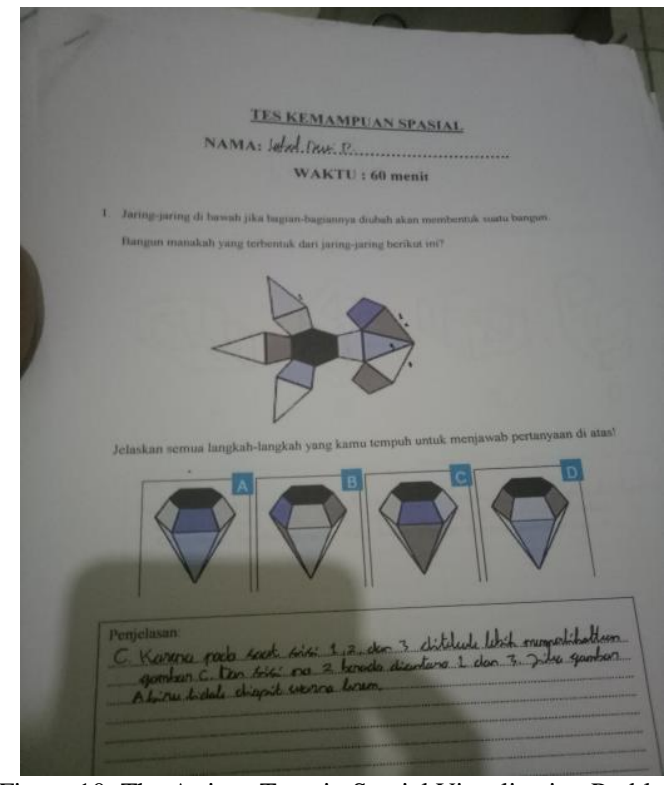

Figure 10: The Artisan Type in Spatial Visualization Problem

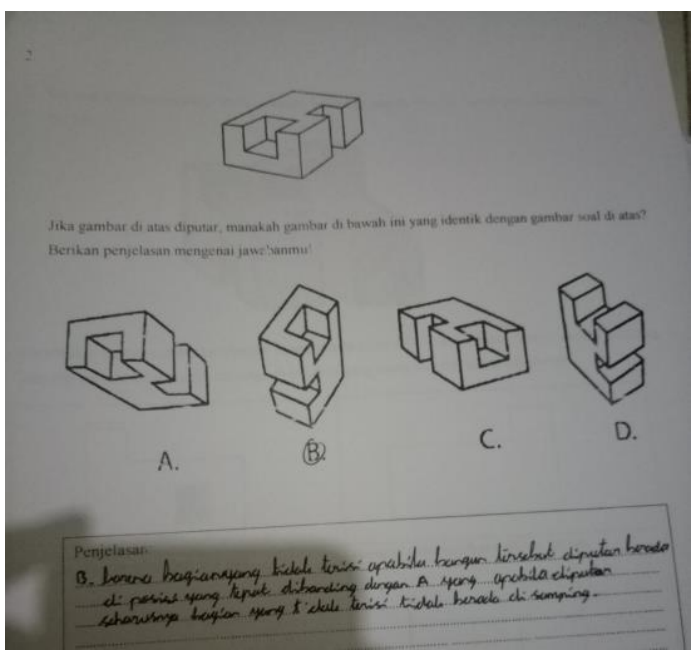

Figure 11: The Artisan Type in Mental Rotation Problem

In spatial visualization, artisan student couldn't identify the figure properly. Based on the interview activities, student expressed his thinking quickly. This was accordance with Keirsey's opinion that artisan student could think of something quickly. This caused an error in the process of identifying the figures. In mental rotation, artisan student could think quickly. Students were also answer questions correctly. It indicated the mental rotation of artisan students was quite good. In spatial orientation, artisan student drew each figure proportionally. It could be seen from the neatness of the figure's drawing. Each figure was also described more detail. Students could understand the difference of the perforated surface. 


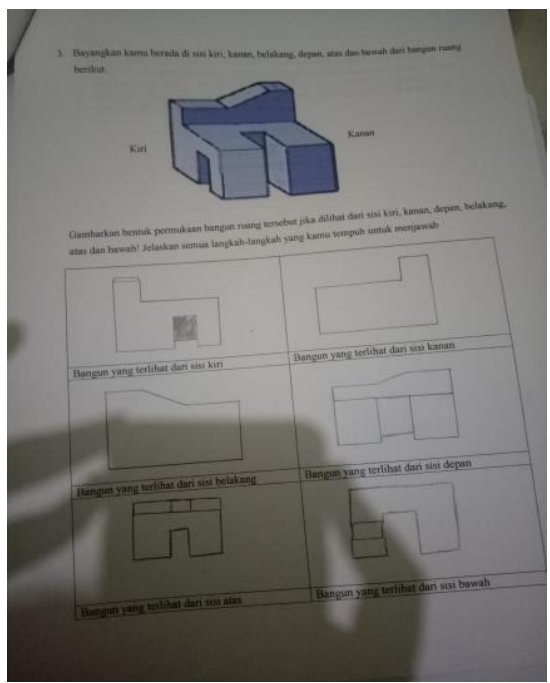

Figure 12: The Artisan Type in Spatial Orientation Problem

\section{CONCLUSION}

In spatial visualization, students who had guardian and artisan personalities could identify the figure with their sensing. The rational student identified the figure with his knowledge. The idealist student had experienced difficulties to identify the figure. In mental rotation guardian and idealist student could imagined the figure that had been rotated. The idealist student had seen the pattern of the figure to solving the problem. The artisan and rational student had answered with the wrong answer because the rational student just focused in angle but ignored the direction of the figure and the artisan student had answered in a hurry. In spatial orientation guardian and artisan personalities had drawn with details. The rational personalities student had drawn without regard the size of the figure.

\section{REFERENCES}

[1] C. Charcharos, M. Kokla, and E. Tomai, ,"Linking Spatial Thingking and Problem-Solving Skills of Young Children", Conference: Inspiring Science Education. Luxembrough, pp. 67-76, 2016.

[2] E. A. Ekinmola, "Developing Mathematical Problem Solving Ability: A Panacea for A Sustainable Development in The 21 $1^{\text {st }}$ Century", International Journal of Education and Research, vol. 2, no. 2, 2014.
[3] W. Huitt, "Problem solving and decision making: Consideration of individual differences using the Myers-Briggs Type Indicator", Journal of Psychological Type, vol. 24, pp. 33-44, 1992.

[4] N. Ibrahimoglu, I. Unaldi, M. Samancioglu, M. Baglibel, "The Relationship Between Personality Traits and Learning Styles: A Cluster Analysis", Leena and Luna International, vol. 2, no. 3, pp. 93-108, 2013.

[5] D. Keirsey, Please Understand MeII, United States of Amerika: Prometheus Nemesis Book Company, 1998.

[6] K. R. Kelly and H. Jugovic, "Concurrent Validity of the Online Version of the KeirseyTemprament Sorter II", Journal of Career Assessment. West Lafayette, vol. 9, no. 1, pp. 49-59, 2001.

[7] Kemendikbud, Pembelajaran dan Penilaian Mata Pelajaran Matematika SMA, Jakarta: Depdiknas, 2016

[8] M. Knauff, C. Jola, G. Strube, "Spatial Reasoning: No Need Visual Information", Springer-Verlag Berlin Heidelberg, 2001, pp. 447-437

[9] N. Koruklu, "Personality and Social Problem-Solving: The Mediating Role of Self -Esteem", 17th European Conference on Personality.Switzerland, vol. 15, no. 2, pp. 481-487, 2001.

[10] T. Lowrie, T. Logan, and A. Ramful, "Spatial Reasoning Influences Students' Performance on Mathematics Tasks", Proceedings of the 39th annual conference of the Mathematics Education Research Group of Australasia, pp. 407-414, 2016

[11] Masriyah and M. H. Firmansyah, "Students' Mathematical Literacy in Solving PISA Problems Based on Keirsey Personality Theory", The 2nd International Joint Conference on Science and Technology (IJCST) 2017, pp. 1-7, 2017

[12] J. Mulligan, "Looking Within And Beyond The Geometry Curriculum: Connecting Spatial Reasoning To Mathematics Learning", ZDM Mathematics Education, vol. 37, pp. 511-517, 2015.

[13] B. J. Phelps, "Behavioral Perspectives on Personality and Self", Association for Behavior Analysis International, 2015

[14] Prabowo, Ardhi, and Ristiani, "Rancang Bangun Instrumen Tes Kemampuan Keruangan Pengembangan Tes Kemampuan Keruangan Hubert Maier dan Identifikasi Penskoram Berdasarkan Teori Van Hielle", Jurnal Pendidikan Matematika, vol. 2, no. 2, 2011

[15] A. Ramful, T. Lowrie, and T. Logan, "Measurement of Spatial Ability: Construction and Validation of the Spatial Reasoning Instrument for Middle School Students", Journal of Psychoeducational Assessment, pp. $1-19,2016$

[16] D. Risalah, T. Nusantara, A. Sutawidjaja, Susiswo, E. B. Irawan, an Musa, "Case Study Spatial Reasoning in Student Junior High Schoo Solve Problems Geometri", IOSR Journal of Mathematics (IOSR-JM), vol. 12 , no. 6, pp. 58-61, 2016.

[17] Ryu, Chong, and Song, "Mathematically Gifted Students' Spatia Visualization Ability of Solid Figures", Proceedings og The 31 Conference of The International Group for The Psychology of Mathematics Education, vol. 4, 2017.

[18] J. W. Santrock, Educational Psychology, New York: The McGraw Hill Companies, 2007 